\title{
Methodological considerations as to quantify nutrient and energy metabolism in lactating sows
}

\author{
K. Jakobsen ${ }^{1}$, P.K. Theil and H. Jørgensen \\ Danish Institute of Agricultural Sciences, \\ Department of Animal Health, Welfare and Nutrition, Research Centre Foulum \\ DK-8830 Tjele, Denmark
}

\begin{abstract}
Protein, fat, carbohydrate and energy metabolism were studied in 8 lactating sows with their litters. Intake of nutrients and energy and excretion in faeces, urine and milk were studied in digestibility and nitrogen $(\mathrm{N})$ and carbon $(\mathrm{C})$ balances, while indirect calorimetry was used to quantify heat $(\mathrm{HE})$ and methane $\left(\mathrm{CH}_{4}\right)$ production. As the piglets have to join the sow during measurements total HE (sow + piglets) was measured. In order to separate total HE into sow HE and piglet $\mathrm{HE}$ different methods were used. The sow milk production was measured by deuterated water $\left(\mathrm{D}_{2} \mathrm{O}\right)$ dilution. By using doubly labelled water $\left(\mathrm{D}_{2}{ }^{18} \mathrm{O}\right)$ in three piglets per litter, the $\mathrm{CO}_{2}$ production of the piglets was measured simultaneously with milk production with high accuracy. The sow $\mathrm{HE}$ was measured from heart rate by implantation of a telemetric transmitter. In addition total HE could be separated into sow HE and piglet HE by dividing the gas exchange according to metabolic liveweight $\left(\mathrm{LW}, \mathrm{kg}^{0.75}\right)$ of sow and piglets and by using factorial methods for sow and piglets. The physical activity of the sow was recorded by means of a photocell. Advantages and disadvantages by using the different methods are discussed.
\end{abstract}

KEY WORDS: indirect calorimetry, deuterium oxide, doubly labelled water, heart rate, milk production, substrate oxidation

\section{INTRODUCTION}

Nutrition of the lactating sow is very complex and demanding under modern genetic, feeding, housing and management systems. The litter size has increased considerably over the last decades, and the size of the sows has increased as well (Moustsen et al., 2004). The voluntary feed intake does not always meet the

$\overline{\text { Corresponding }}$ author: e-mail: Kirsten.Jakobsen@agrsci.dk 
requirements of the sow for energy and nutrients, resulting in mobilization of body tissues (Neil et al., 1996), which may affect future reproduction negatively (King et al., 1984). The selection for lean pigs has further charged the ability of sows to mobilize body fat during lactation and reduced the voluntary feed intake (Cole, 1990). The EU-legislation demands more welfare-oriented production systems and less pollution of the environment with nutrients and gases. The demands of a modern production system is to satisfy not only nutritional requirements, but also the health and welfare of the sow and her piglets, to minimize the pollution of the environment and to optimize the economy of the production. Most studies have been concerned with observations of the production rate of sows and piglets, registering input and output, observing abnormalities such as diarrhoea and unthriftiness, the condition of the sow etc. However, studies concerning the metabolism of nutrients and energy of the sow are scarce, the sow being looked upon virtually as a black box. There are obvious methodological, economical and practical difficulties in measuring nutrient and energy metabolism in the lactating sow, partly due to her size compared to that of growing pigs, partly due to the suckling activity of the piglets which cannot be separated from their mother without imposing stress on both mother and offspring. However, in order to be able to optimize the performance of the lactating sow and her piglets and to prevent metabolic disorders, a better understanding of lactogenesis and the regulation of nutrient supply of the mammary glands and the body tissues under different feeding and housing concepts is fundamental.

The aim of the present paper is to evaluate the methods used in the studies performed in our laboratory to quantify nutrient and energy metabolism in lactating sows by using nitrogen $(\mathrm{N})$ and carbon $(\mathrm{C})$ balance experiments, indirect calorimetry (RQ - and $\mathrm{CN}$ - method), doubly labelled water (DLW, $\mathrm{D}_{2}{ }^{18} \mathrm{O}$ ) for measurement of milk production $\left(\mathrm{D}_{2} \mathrm{O}\right)$ and $\mathrm{CO}_{2}$ production $\left(\mathrm{D}_{2}{ }^{18} \mathrm{O}\right)$ of the piglets, and telemetry for measurement of heart rate of the sow to estimate her heat production (HE). The physical activity of the sow was recorded by means of a photocell installed in the metabolism cage during measurement of gas exchange in the respiration chambers.

\section{MATERIAL AND METHODS}

Eight LY-sows (Danish Landrace x Yorkshire) of second parity were included in the measurements. Early in the pregnancy period a telemetric transmitter (TA1OCTA - D70, Data Science International, St. Paul, USA) for measuring heart rate and body temperature was implanted subcutaneously under general anaesthesia, ventrally close to the sternum. Heart rate (HR) was used for prediction of the heat production (HE) of the lactating sow. Prior to the study in the lactation period the sows had been 
subjected to four balance and respirationtrials in the pregnancy period. They were fed two different protein levels (18.3 and $13.5 \%$ crude protein). The results from these trials are published by Theil et al. (2002a). In the lactation period four sows received a low fat diet with $3.1 \%$ crude fat (HCl-fat) and the other four sows a high fat diet with $11.3 \%$ crude fat. The basal diet consisted of barley, wheat, soyabean meal, minerals and vitamins, and animal fat was added to the high fat diet. Chromic oxide $\left(2 \mathrm{~g} \mathrm{~kg}^{-1}\right)$ was added as a marker to the diets. Sows were fed twice daily $(07.30$ and $15.00 \mathrm{~h}$ ) and they had free access to water. The feeding level was gradually increased within the first 10 days of lactation, until the daily supply of $24.60 \mathrm{MJ} \mathrm{ME}$ plus additionally 6.15 MJ ME for each piglet in the litter was reached. The suckling piglets had no access to creep feed or water. Feed residues were analysed for dry matter. Details about animals, diets and analyses of feed, faeces, urine and milk are described by Theil et al. (2004b). For the present purpose the results from the eight lactating sows have been pooled.

Sows with their litters were kept in individual pens $(200 \times 300 \mathrm{~cm})$ until weaning at $28 \mathrm{~d}$ post partum except during balance periods where they were kept in metabolism cages. The total heat production (HE) of sow + litter was measured in three balance periods each of three days, approx. on d 10, 17 and 24 of lactation for $2 \times 24 \mathrm{~h}$, while sow and piglets were placed in metabolism cages of stainless steel (size $2.4 \times 1.1 \times 0.8 \mathrm{~m}$ ). An adjacent metabolism cage offered a place for piglets to rest and to urinate/defaecate, which allowed separate collection. Sulphuric acid $(50 \mathrm{ml}, 30 \%)$ was added to the container for urine collection to prevent evaporative loss of ammonia. The sows were not fitted with urinary catheters to avoid the risk of infection. Two respiration chambers built according to the open-air circulation principle as described by Jørgensen et al. (1996) were used for measurement of $\mathrm{O}_{2}$ consumption (paramagnetic principle, Magnos $4 \mathrm{G}$, Hartmann and Braun, Frankfurt, Germany) and $\mathrm{CO}_{2}$ and $\mathrm{CH}_{4}$ production (infrared principle, Uras 3, Hartmann and Braun, Frankfurt, Germany). A 12 h (06:00-18.00 h) light-dark cycle was operated. Temperature and relative humidity were kept constant in the respiration chambers and in the pens at $20.7 \pm 0.9^{\circ} \mathrm{C}$ and $67 \pm 5 \%$, respectively. Nitrogen and carbon balances were derived from the data obtained.

Milk production was measured by means of dilution of deuterium oxide in three piglets per litter enriched with doubly labelled water $\left(\mathrm{D}_{2}{ }^{18} \mathrm{O}\right)$ as described in details by Theil et al. (2002b). In week 2 an i.p. injection of a single dose of 0.5 g DLW per kg LW enriched the piglets. The DLW was a mixture of two thirds of $97 \% \mathrm{H}_{2}^{18} \mathrm{O}$ (Isotech, Netherlands) and one third of $99.9 \% \mathrm{D}_{2} \mathrm{O}$ (Bie and Berntsen, Rødovre, Denmark). An initial blood sample was drawn from vena jugularis from each piglet for determination of the background level of $\mathrm{D}_{2} \mathrm{O}$ and $\mathrm{H}_{2}{ }^{18} \mathrm{O}$. Consecutive blood samples were drawn from the enriched piglets on days 3, 7 and 10 after enrichment. The serum content of $\mathrm{D}_{2} \mathrm{O}$ and ${ }^{18} \mathrm{O}$ was measured by isotope ratio mass spectrometry as described by Theil et al. (2003). Milk samples 
were taken from the sow at the end of each balance period in order to measure the chemical composition of the milk. Sows were hand-milked after i.v. injection of $10 \mathrm{IU}(1 \mathrm{ml})$ of oxytocin (Løvens Kemiske Fabrik, Ballerup, Denmark) in an ear vein. Milk from different glands was pooled within sow, filtered through cheese cloth and stored at $-18^{\circ} \mathrm{C}$ until analysed.

The physical activity of the sows in the respiration chambers was confined to either standing or lying in the metabolism cage. The standing activity was recorded continuously by means of a photocell (OA 722 NPN/PNP, T.J.C. Teknik aps, Virum, Denmark) throughout the respiration trials except for two sows.

Dietary carbohydrates $(\mathrm{CHO})$ were calculated as the difference between dry matter $(\mathrm{DM})$ and the sum of protein $(\mathrm{N} \times 6.25)$, Stoldt fat $(\mathrm{HCl}-\mathrm{fat})$ and ash :

$$
\mathrm{CHO}, \mathrm{g} \mathrm{kg}^{-1} \mathrm{DM}=\mathrm{DM}-(\text { protein }+ \text { fat }+ \text { ash })
$$

Digestibility of energy and nutrients was calculated based on the chromic oxide technique.

Nitrogen metabolism: The nitrogen $(\mathrm{N})$ balance which is equal to retained $\mathrm{N}$ $(\mathrm{RN})$ expressed in $\mathrm{g} \mathrm{d}^{-1}$ was measured as:

$$
\mathrm{RN}, \mathrm{g} \mathrm{d}^{-1}=\mathrm{g} \mathrm{N} \text { in feed }-(\mathrm{g} \mathrm{N} \text { in faeces }+\mathrm{g} \mathrm{N} \text { in urine }+\mathrm{g} \mathrm{N} \text { in milk })
$$

The protein balance (RP) was obtained by multiplying $\mathrm{N}$ in feed, faeces and urine by the factor 6.25 and $\mathrm{N}$ in milk by 6.38 . Faeces and urine were collected separately under the sow metabolism cage and were assumed to originate solely from the sow.

Energy metabolism was measured both in sows and piglets during the balance and respiration trials. HE was measured for the sow alone when using heart rate (HR) measurements, and for the piglets alone when using DLW-technique.

The contribution of the sow or the piglets to total HE was determined by the following six different methods:

1. RQ-method: The $\mathrm{O}_{2}$ consumption and $\mathrm{CO}_{2}$ production was separated into sow and piglet contributions according to their respective metabolic liveweights $(\mathrm{kg}$ ${ }^{0.75}$ ), and HE was calculated according to Brouwer (1965) as:

$$
\begin{gathered}
\mathrm{HE}(\mathrm{RQ}), \mathrm{kJ} \mathrm{d}^{-1}=\text { litres } \mathrm{O}_{2} \times 16.18+\text { litres } \mathrm{CO}_{2} \times 5.02-\text { litres } \mathrm{CH}_{4} \times 2.17 \\
-\mathrm{g} \mathrm{UN} \times 5.9
\end{gathered}
$$

where $\mathrm{UN}$ is $\mathrm{N}$ in urine. Retained energy (RE) describing the energy balance was derived as the difference between metabolizable energy (ME), and the sum of $\mathrm{HE}(\mathrm{RQ})$ and energy in milk (LE), where ME is gross energy (GE) in feed minus loss of energy in faeces (FE), urine (UE) and, methane $\left(\mathrm{CH}_{4} \mathrm{E}\right)$, thus: 


$$
\begin{aligned}
& \mathrm{RE}(\mathrm{RQ}), \mathrm{kJ} \mathrm{d}^{-1}=\mathrm{ME}-(\mathrm{HE}(\mathrm{RQ})+\mathrm{LE}) \\
& \mathrm{ME}, \mathrm{kJ} \mathrm{d}^{-1}=\mathrm{GE}-\left(\mathrm{FE}+\mathrm{UE}+\mathrm{CH}_{4} \mathrm{E}\right)
\end{aligned}
$$

Total HE was separated into sow and piglet contribution by dividing all measurements of gas exchange according to the metabolic liveweight of the sow and the piglets, whereby the RQ of sow and piglets was assumed to be equal. This approach is described for mink to separate total HE of lactating mink dams and suckling kits measured by indirect calorimetry (Fink, 2004). Raising the liveweight of individual piglets to the power of 0.75 and taking the sum gave the metabolic liveweight of the litter.

Retained energy in fat (RF), which is of interest to follow during lactation can be derived as the difference between RE(RQ) and RP, thus:

$$
\mathrm{RF}(\mathrm{RQ}), \mathrm{kJ} \mathrm{d}^{-1}=\mathrm{RE}(\mathrm{RQ})-\mathrm{RP}
$$

2. CN-method: This method is based on measurements of the carbon and nitrogen balances. The carbon balance which is equal to the carbon retention was measured as the difference in $\mathrm{C}$ intake and $\mathrm{C}$ in excretions in $\mathrm{g} \mathrm{d}^{-1}$ as:

$$
\begin{gathered}
\text { C-balance, } \mathrm{g} \mathrm{d}^{-1}=\mathrm{C} \text { in feed }-\left(\mathrm{C} \text { in faeces }+\mathrm{C} \text { in urine }+\mathrm{C} \text { in } \mathrm{CO}_{2}\right. \\
\left.+\mathrm{C} \text { in } \mathrm{CH}_{4}+\mathrm{C} \text { in milk }\right)
\end{gathered}
$$

Retained energy, $\mathrm{RE}(\mathrm{CN})$, was determined, and the heat production $\mathrm{HE}(\mathrm{CN})$ was calculated as the difference between $\mathrm{ME}$ and $\mathrm{RE}(\mathrm{CN})$. $\mathrm{C}$ in $\mathrm{CO}_{2}$ was separated into sow and piglet contribution according to their metabolic liveweights. The retained energy was the sum of retained energy in protein and fat. Energy retained in protein (RP) was calculated based on the $\mathrm{N}$ balance $\left(\mathrm{g} \mathrm{d}^{-1}\right)$, while energy retained in fat (RF) was calculated by means of the carbon balance, corrected for retained carbon in protein as described by Christensen et al. (1988).

$$
\begin{gathered}
\mathrm{RP}, \mathrm{kJ} \mathrm{d}^{-1}=\mathrm{N}-\text { balance } \times 6.25 \times 23.86 \\
\mathrm{RF}(\mathrm{CN}), \mathrm{kJ} \mathrm{d}^{-1}=(\mathrm{C} \text {-balance- }(\mathrm{N}-\text { balance } \times 6.25 \times 0.52)) \times 39.76 / 0.767 \\
\mathrm{RE}(\mathrm{CN}), \mathrm{kJ} \mathrm{d}^{-1}=\mathrm{RP}+\mathrm{RF}(\mathrm{CN}) \\
\mathrm{HE}(\mathrm{CN}), \mathrm{kJ} \mathrm{d}^{-1}=\mathrm{ME}-\mathrm{RE}(\mathrm{CN})
\end{gathered}
$$

3. Heart rate (HR) method: Sow HE was predicted by means of mean daily HR, DM intake and LW as: 
$\mathrm{HE}\left(\mathrm{kJ} \mathrm{d}^{-1}\right)=\mathrm{HR}\left(\right.$ beats $\left.\min ^{-1}\right) \times \gamma+3602 \times \mathrm{kg} \mathrm{DM}$ intake

$$
+27.0 \times \mathrm{kg} \mathrm{LW}+6008 \mathrm{~kJ} \mathrm{~d}^{-1}
$$

The relation between HE and HR $(\gamma)$ was calibrated individually during pregnancy (Theil and Jørgensen, 2002) and was on average $82 \mathrm{~kJ}^{\text {beat }}{ }^{-1} \mathrm{~min}^{-1}$.

4. DLW-method: By means of the doubly labelled water (DLW) technique the $\mathrm{CO}_{2}$ production of piglets was measured concomitantly with the milk intake by dilution of deuterated water. The rate of $\mathrm{CO}_{2}$ production $\left(\mathrm{rCO}_{2}\right)$ was calculated by the single pool model proposed by Lifson and McClintock (1966) and $\mathrm{rCO}_{2}$ was converted from mol d $\mathrm{d}^{-1}$ to litres $\mathrm{d}^{-1}\left(\mathrm{Ld}^{-1}\right)$ of $\mathrm{CO}_{2}$ by multiplying with the constants $0.08205\left(\mathrm{~atm} \times \mathrm{L} \mathrm{x} \mathrm{mol}^{-1} \times \mathrm{K}^{-1}\right)$ and $273.15 \mathrm{~K}$.

$$
\mathrm{rCO}_{2}\left(\mathrm{Ld}^{-1}\right)=\mathrm{Q} \times\left(0.480769 \times \mathrm{k}_{\mathrm{o}}-0.495769 \times \mathrm{k}_{\mathrm{D}}\right) \times 0.08205 \times 273.15
$$

where $\mathrm{Q}$ was total body water, and $\mathrm{k}_{\mathrm{o}}$ and $\mathrm{k}_{\mathrm{D}}$ were the fractional turnover rates of ${ }^{18} \mathrm{O}$ and $\mathrm{D}_{2} \mathrm{O}$, respectively.

Litter $\mathrm{CO}_{2}$ production was measured in three piglets per litter and based on these measurements, $\mathrm{CO}_{2}$ production was calculated for the remaining littermates by means of their LW (Theil et al., 2003). The piglet HE was calculated according to Brouwer (1965) by assuming that piglet RQ was equal to 0.84 (Noblet and Etienne, 1987b). Finally, the sow HE was found as the difference between total $\mathrm{HE}$ and litter HE. In week 4 of lactation, the DLW enrichment was too low, because the piglets were only enriched once (in week 2). Consequently, the $\mathrm{CO}_{2}$ production in week 4 of lactation was predicted for all piglets based on their LW by the following equation:

$$
\text { individual piglet } \mathrm{rCO}_{2} \text {, week } 4\left(\mathrm{Ld}^{-1}\right)=25.75 \times \mathrm{LW}-1.01 \times \mathrm{LW}^{2}
$$

For comparison, sow and piglet HE was calculated factorially. The piglet HE measured by means of DLW or calculated factorially was used to subtract from the total HE (sow + litter), to estimate the sow HE.

5. Piglet factorial method (pig FM): According to Verstegen et al. (1985), litter HE could be predicted as:

$\mathrm{HE}\left(\right.$ piglets, $\left.\mathrm{kJ} \mathrm{d}^{-1}\right)=460 \mathrm{~kJ} \mathrm{~kg}^{-0.75} \mathrm{~d}^{-1} \times$ litter LW, $\mathrm{kg}^{0.75}+0.195 \times \mathrm{LE}$ where LE was the energy intake from milk $\left(\mathrm{kJ} \mathrm{d}^{-1}\right)$.

6. Sow factorial method (sow FM): According to Noblet and Etienne (1987a), lactating sow HE could be predicted as: 
$\mathrm{HE}\left(\right.$ sow, $\left.\mathrm{kJ} \mathrm{d} \mathrm{d}^{-1}\right)=460 \mathrm{~kJ} \times \mathrm{LW}, \quad \mathrm{kg}^{-0.75} \mathrm{~d}^{-1} \times \mathrm{LW}, \mathrm{kg}^{0.75}+$ $\mathrm{LE} / 0.72-\mathrm{LE}, \mathrm{kJ} \mathrm{d}^{-1}$

where 0.72 was the overall efficiency of utilization of ME for milk production and LE was the energy output in milk.

Milk production was measured by means of the DLW-technique concomitantly allowing measurement of the $\mathrm{CO}_{2}$ production as described above. Three piglets were enriched with $\mathrm{D}_{2}{ }^{18} \mathrm{O}$ in week 2 . The milk intake was calculated as the sum of the water turnover and the potential metabolic water stored (PMWS), divided by the potential water fraction of the milk. For a detailed description of calculations of milk intake, see Theil et al. (2002b).

Milk intake in piglet $\left(\mathrm{g} \mathrm{d}^{-1}\right)=\frac{\text { water turnover }+ \text { PMWS }}{\text { potential water fracation of milk }}$

Sow milk production was calculated by summing the milk intake of individual piglets, the estimation of the milk intake from the remaining littermates being based on their daily rate of LW gain. However, in week 4 of lactation, $\mathrm{D}_{2} \mathrm{O}$ enrichment was too low and consequently the milk intake in that week was found by the equation (Theil et al., 2002b):

Milk intake in piglet, week $4\left(\mathrm{~g} \mathrm{~d}^{-1}\right)=582+1.168 \times$ piglet gain +0.00425 $\times$ piglet gain ${ }^{2}$

Standing activity: Energy cost of standing activity was calculated according to Noblet et al. (1993) as follows:

Standing activity $\left(\mathrm{kJ} \mathrm{d}^{-1}\right)=14.9 \mathrm{~kJ} \mathrm{~min}^{-1} \times \mathrm{St}_{\text {act }}, \min . \mathrm{d}^{-1}$

Oxidation of nutrients: Based on the gas exchange and $\mathrm{N}$ in urine (UN), oxidation of protein (OXP), carbohydrate (OXCHO) and fat (OXF) and the nonprotein respiratory quotient $\left(\mathrm{RQ}_{\mathrm{np}}\right)$ was calculated according to Chwalibog et al. (1992):

$$
\mathrm{OXP}, \mathrm{kJ}=\mathrm{UN}, \mathrm{g} \times 6.25 \times 18.42 \mathrm{~kJ} \mathrm{~g}^{-1}
$$

OXCHO, $\mathrm{kJ}=\left(-2.968 \times \mathrm{O}_{2}, \mathrm{~L}+4.174 \times \mathrm{CO}_{2}, \mathrm{~L}-2.446 \times \mathrm{UN}, \mathrm{g}\right) \times 39.76 \mathrm{~kJ} \mathrm{~g}^{-1}$

$$
\begin{gathered}
\text { OXF, } \mathrm{kJ}=\left(1.719 \times \mathrm{O}_{2}, \mathrm{~L}-1.719 \times \mathrm{CO}_{2}, \mathrm{~L}-1.963 \times \mathrm{UN}, \mathrm{g}\right) \times 39.76 \mathrm{~kJ} \mathrm{~g}^{-1} \\
\mathrm{RQ}_{\mathrm{np}}=\left(\mathrm{CO}_{2}, \mathrm{~L}-(\mathrm{UN}, \mathrm{g} \times 0.774) /\left(\mathrm{O}_{2}, \mathrm{~L}-(\mathrm{UN}, \mathrm{g} \times 0.957)\right.\right.
\end{gathered}
$$


The Danish Experimental Inspectorate, Ministry of Justice, Copenhagen (Denmark), approved these experiments.

Statistical analyses: Observations of protein-, fat-, carbohydrate-, and energy metabolism and nutrient oxidation were analysed using a normal mixed model (Littell et al., 1996). The observations were dependent in all these analyses because repeated measurements were collected over time during the lactation period. A random component was incorporated into the statistical analyses to account for this correlation structure. The milk production was estimated based on the milk intake of three piglets per litter. Therefore, milk production was analysed by including two random components to account for repeated measurements within the same sow (different piglets) and repeated measurements within the same piglet (different weeks of lactation), respectively. Values are reported as LS means \pm standard error (SE).

\section{RESULTS}

The sows weighed on average $216 \pm 6 \mathrm{~kg}$ (SE) after farrowing and lost on average $17.7 \pm 1.2 \mathrm{~kg}$ during lactation. Mean $\pm \mathrm{SE}$ of number of liveborn piglets per litter was $11.3 \pm 1.6$ and $0.5 \pm 0.4$ were stillborn. The sows weaned $9.3 \pm 0.9$ piglets per litter. Piglet LW at birth was $1.27 \pm 0.16 \mathrm{~kg}$ and at weaning on $\mathrm{d} 28$ $7.51 \pm 0.73 \mathrm{~kg}$, the average rate of gain being $223 \pm 23 \mathrm{~g} \mathrm{~d}^{-1}$. Three sows developed mastitis and were treated. DM intake of sows, liveweight and metabolic liveweight of sows and litters together with the milk production on d 10,17 and 24 of lactation are shown in Table 1.

Table 1. Liveweight (LW), metabolic liveweight ( $\mathrm{LW}, \mathrm{kg}^{0.75}$ ) dry matter (DM) intake and milk production of sows on d 10, 17 and 24 of lactation (mean and SE of 8 sows)

\begin{tabular}{lcccccc}
\hline Lactation day & 10 & 17 & 24 & Mean & SE & P-value \\
Lactation week & 2 & 3 & 4 & & & \\
\hline Sow & & & & & & \\
$\quad$ LW, kg & 208 & 206 & 200 & 205 & 6.0 & 0.005 \\
LW, kg.75 & 54.7 & 54.3 & 53.2 & 54.1 & 1.3 & 0.005 \\
DM, intake, $\mathrm{kg} \mathrm{d}^{-1}$ & 4.52 & 4.70 & 5.22 & 4.81 & 0.30 & 0.02 \\
$\quad$ Milk yield, kg d & 7.69 & 9.50 & 10.6 & 9.28 & 0.73 & $<0.001$ \\
& & & & & & \\
Litter & 29.3 & 43.7 & 58.0 & 43.7 & 2.4 & $<0.001$ \\
LW, kg & 21.8 & 29.4 & 36.4 & 29.2 & 1.7 & $<0.001$ \\
LW, kg.75 & & & & & & \\
\hline
\end{tabular}

In order to avoid feed residues the sows were fed restrictedly, although as close to ad libitum as possible. The feed intake was raised daily until d 10 according to litter size and few feed residues occurred in week 1 and 3. 
Milk production was measured by enriching 3 piglets per litter with DLW. Fitting the relation between milk intake and piglet rate of gain for the three median piglets in week 2 and 3 according to Theil et al. (2002b) gave the following equation: Milk intake, week $2\left(\mathrm{~g} \mathrm{~d}^{-1}\right)=337+2.963 \times$ piglet gain. Milk intake, week $3\left(\mathrm{~g} \mathrm{~d}^{-1}\right)=390+2.963 \times$ piglet gain.

These equations were used to predict the milk intake of non-enriched littermates. Summation of the observed (3 piglets per litter) and predicted milk intake ( $n-3$ piglets per litter) estimated the milk production of the sows.

In week 4 of lactation, the $\mathrm{D}_{2} \mathrm{O}$ enrichment was too low and the milk intake by individual littermates was predicted by equation (18), and the estimates were used to predict the milk production of the sow.

The chemical composition of the milk was not affected by the stage of lactation ( $P>0.05$ ). On average, the milk contained $17.7 \%$ DM and on DM basis, \%: crude fat 37.5 , crude protein 28.1 , lactose 29.9 and crude ash 4.6. The gross energy concentration of the milk was $25.54 \mathrm{MJ} \mathrm{kg} \mathrm{DM}^{-1}$.

Digestibility of nutrients was determined using chromic oxide as a marker. The stage of lactation did not influence the digestibility of nutrients and energy $(\mathrm{P}>0.05)$. The digestibility coefficient for protein was $82.7 \pm 0.5 \%$, carbohydrates $89.5 \pm 0.5 \%$, fat $62.3 \pm 3.5 \%$, DM $84.1 \pm 0.7 \%$ and energy $83.7 \pm 0.7 \%$. Nitrogen intake and $\mathrm{N}$ excreted in faeces and urine increased during the lactation period, while $\mathrm{N}$ excreted in milk increased considerably $(\mathrm{P}<0.01)$ from $60.2 \mathrm{~g} \mathrm{~N} \mathrm{~d}^{-1}$ in week 2

Table 2. Nitrogen balance, nitrogen utilization and fat metabolism in sows on d 10, 17 and 24 of lactation (mean and SE of 8 sows)

\begin{tabular}{|c|c|c|c|c|c|c|}
\hline \multirow{2}{*}{$\begin{array}{l}\text { Lactation day } \\
\text { Lactation week }\end{array}$} & 10 & 17 & 24 & \multirow{2}{*}{ Mean } & \multirow{2}{*}{ SE } & \multirow{2}{*}{ P-value } \\
\hline & 2 & 3 & 4 & & & \\
\hline \multicolumn{7}{|l|}{$N$-balance, $g d^{-1}$} \\
\hline $\mathrm{N}$ intake & 137.3 & 142.0 & 157.9 & 145.7 & 8.9 & 0.02 \\
\hline $\mathrm{N}$ in faeces & 23.3 & 24.5 & 28.0 & 25.3 & 1.9 & 0.04 \\
\hline $\mathrm{N}$ in urine & 38.7 & 43.8 & 43.4 & 42.0 & 4.5 & 0.64 \\
\hline $\mathrm{N}$ in milk & 60.2 & 73.0 & 82.8 & 72.0 & 6.0 & 0.004 \\
\hline $\mathrm{N}$ retained & 15.1 & 0.7 & 3.7 & 6.5 & 4.3 & 0.05 \\
\hline \multicolumn{7}{|c|}{$N$-utilization, \% of intake } \\
\hline $\mathrm{N}$ in faeces & 16.8 & 17.2 & 17.8 & 17.3 & 0.6 & 0.36 \\
\hline $\mathrm{N}$ in urine & 28.2 & 30.5 & 27.6 & 28.8 & 2.2 & 0.62 \\
\hline $\mathrm{N}$ in milk & 43.9 & 51.7 & 52.3 & 49.3 & 2.7 & 0.07 \\
\hline $\mathrm{N}$ retained & 11.0 & 0.6 & 2.4 & 4.7 & 2.8 & 0.03 \\
\hline \multicolumn{7}{|c|}{ Fat metabolism, $g d^{-1}$} \\
\hline intake & 332 & 330 & 370 & 344 & 77 & 0.08 \\
\hline digested & 225 & 223 & 247 & 232 & 60 & 0.17 \\
\hline fat in milk & 525 & 634 & 230 & 630 & 60 & 0.01 \\
\hline mobilized $^{1}$ & 106 & 193 & 128 & 142 & 70 & 0.60 \\
\hline
\end{tabular}

\footnotetext{
${ }^{1}$ calculated according to the RQ-method (eq. 6)
} 
to $82.8 \mathrm{~g} \mathrm{~N} \mathrm{~d}^{-1}$ in week 4 of lactation (Table 2). Relative to intake, the amount of $\mathrm{N}$ excreted in faeces and urine was constant, while the utilization of $\mathrm{N}$ for milk production increased with progress of lactation. In week 2 of lactation, where the milk production was lowest, the retained $\mathrm{N}(\mathrm{RN})$ in the sow was $15 \mathrm{~g} \mathrm{~d}^{-1}$, while $\mathrm{RN}$ was reduced to $3.7 \mathrm{~g} \mathrm{~d}^{-1}$ in week 4 (Table 2). The mobilization of body fat was $142 \mathrm{~g}$ $\mathrm{d}^{-1}$ on average for the lactation period with minor changes as shown in Table 2.

Heat production of lactating sows and their litters assessed by different approaches are shown in Table 3 . Total HE of sow and litter measured by indirect calorimetry and calculated according to equation (3) increased with progress of lactation $(\mathrm{P}<0.001)$. The percentage deviation of the different methods was calculated relative to the RQ-method separated according to metabolic liveweight of sows and piglets. For all methods HE of sows was found to be fairly constant during the lactation period with deviations from the RQ-method from +8 to $8 \%$. HE of suckling piglets increased during the lactation period with differences between methods from +14 to $-15 \%$ of that of the RQ-method.

Table 3. Total heat production (HE, $\mathrm{MJ} \mathrm{d}^{-1}$ ) of sow and litter and $\mathrm{HE}$ of sow and litter per se on $\mathrm{d} 10$, 17 and 24 of lactation assessed by different methods (mean and SE of 8 sows)

\begin{tabular}{|c|c|c|c|c|c|c|c|}
\hline \multirow{2}{*}{$\begin{array}{l}\text { Lactation day } \\
\text { Lactation week }\end{array}$} & \multirow{2}{*}{$\begin{array}{c}10 \\
2\end{array}$} & \multirow{2}{*}{$\begin{array}{c}17 \\
3\end{array}$} & \multirow{2}{*}{$\begin{array}{c}24 \\
4\end{array}$} & \multirow[t]{2}{*}{ Mean } & \multirow{2}{*}{$\begin{array}{c}\text { Deviation } \\
\%\end{array}$} & \multirow{2}{*}{$\mathrm{SE}$} & \multirow{2}{*}{ P-value } \\
\hline & & & & & & & \\
\hline \multicolumn{8}{|l|}{ HE sow + piglets } \\
\hline RQ-method & 53.89 & 59.39 & 63.25 & 58.84 & - & 2.33 & $<0.001$ \\
\hline \multicolumn{8}{|l|}{ HE of lactating sows } \\
\hline RQ-method & 38.36 & 38.35 & 37.45 & 38.05 & - & 1.00 & 0.28 \\
\hline CN-method & 35.15 & 36.45 & 33.92 & 35.17 & -7.6 & 1.27 & 0.26 \\
\hline heart rate & 35.94 & 36.37 & 38.13 & 36.81 & -3.3 & 1.28 & 0.36 \\
\hline DLW & 37.27 & 37.73 & 36.64 & 37.21 & -2.2 & 1.15 & 0.22 \\
\hline factorial piglets & 38.16 & 39.19 & 39.01 & 38.79 & 1.9 & 1.27 & 0.37 \\
\hline factorial sow & 38.88 & 41.45 & 43.36 & 41.23 & 8.4 & 1.42 & 0.02 \\
\hline \multicolumn{8}{|l|}{ HE of suckling piglets } \\
\hline RQ-method & 15.53 & 21.04 & 25.80 & 20.79 & - & 1.68 & $<0.001$ \\
\hline CN-method & 18.74 & 22.94 & 29.32 & 23.65 & 13.8 & 2.18 & 0.14 \\
\hline heart rate & 17.95 & 23.02 & 25.12 & 22.03 & 6.0 & 1.67 & $<0.001$ \\
\hline DLW & 16.62 & 21.66 & 26.61 & 21.63 & 4.0 & 1.48 & $<0.001$ \\
\hline factorial piglets & 15.72 & 20.20 & 24.24 & 20.06 & -3.5 & 1.33 & $<0.001$ \\
\hline factorial sow & 15.01 & 17.95 & 19.88 & 17.61 & -15.2 & 1.63 & 0.24 \\
\hline
\end{tabular}

the different methods are described in Materials and Methods

Energy balance of sows is shown in Table 4. ME intake was on average 15.43 MJ kg DM ${ }^{-1}$ corresponding to $96.4 \%$ of digestible energy. Of this $2.9 \%$ was lost in urine and $0.7 \%$ in methane with no significant differences between days of lactation. 
Expressed in relation to metabolic LW, however, ME increased from 1294 to 1516 $\mathrm{kJ} \mathrm{kg}^{-0.75} \mathrm{~d}^{-1}(\mathrm{P}=0.006)$ from week 2 to 4 of lactation. Energy excreted in milk (LE) increased from 50.1 to $60.2 \%$ of $\mathrm{ME}(\mathrm{P}=0.07)$ and 650 to $914 \mathrm{~kJ} \mathrm{~kg}^{0.75} \mathrm{~d}^{-1}$ $(\mathrm{P}<0.001)$ with progress of lactation. Furthermore, HE decreased from 53.2 to $46.5 \%$ of $\mathrm{ME}(\mathrm{P}=0.03)$ and was fairly constant during the lactation period when expressed in relation to metabolic LW. Retained energy was negative during the whole lactation period constituting on average $6.4 \%$ of $\mathrm{ME}(\mathrm{P}=0.22)$ with a slightly positive retention of protein and negative retention of fat. The standing activity of sows was not affected by the stage of lactation and amounted $194 \mathrm{~min}^{-1}$ corresponding to $54 \mathrm{~kJ} \mathrm{~kg}^{-0.75}$, which is only about $4 \%$ of ME and about $8 \%$ of HE.

Table 4. Energy metabolism and cost of standing activity $\left(\mathrm{kJ} \mathrm{kg} \mathrm{LW}^{-0.75} \mathrm{~d}^{-1}\right)$ of sows on $\mathrm{d} 10,17$ and 24 of lactation (mean and SE of 8 sows)

\begin{tabular}{lrrrrrr}
\hline Lactation day & 10 & 17 & 24 & Mean & SE & P-value \\
Lactation week & \multicolumn{1}{c}{2} & \multicolumn{1}{c}{3} & \multicolumn{1}{c}{4} & & & 0.006 \\
\hline ME & 1294 & 1335 & 1516 & 1381 & 97 & $<0.001$ \\
LE & 650 & 790 & 914 & 785 & 76 & 0.56 \\
HE & 679 & 692 & 684 & 685 & 24 & 0.32 \\
RE & -35 & -148 & -83 & -88 & 52 & 0.06 \\
RP & 42 & 1 & 11 & 18 & 12 & 0.52 \\
RF & -76 & -149 & -94 & -107 & 51 & 0.92 \\
Activity & 55 & 52 & 55 & 54 & 6 & \\
\hline
\end{tabular}

calculated according to RQ-method and standing activity according to equation (18)

Substrate oxidation was similar during the lactation stage $(\mathrm{P}>0.05)$ with a nonprotein respiratory quotient $\left(\mathrm{RQ}_{\mathrm{np}}\right)$ for sows of 1.04 (range $\left.0.99-1.10\right)$ distributed on average with $13.0 \%$ on protein (range $11.5-14.6$ ), $82.2 \%$ on carbohydrates (range $79.1-85.4 \%$ ) and $4.8 \%$ on fat (range $0.0-8.8 \%$ ) with slightly higher values for the sows receiving fat in the diet.

\section{DISCUSSION}

The present studies using indirect calorimetry, stable isotopes and telemetry allowed us to get an insight into energy and nutrient metabolism of protein, fat and carbohydrates as a group of substrates for deposition and oxidation. The present experiments did not study the metabolism of individual nutrients such as glucose, specific amino acids or specific fatty acids although the use of ${ }^{13} \mathrm{C}$ and ${ }^{15} \mathrm{~N}$ would allow such studies. There are, however, advantages and disadvantages with the present studies. They require expensive equipment: metabolism cages of stainless steel for sows and piglets, respiration chambers with gas-analysers for $\mathrm{O}_{2}, \mathrm{CO}_{2}$ and $\mathrm{CH}_{4}$, equipment for measurement of $\mathrm{D}_{2} \mathrm{O}$ and ${ }^{18} \mathrm{O}$, surgery facilities 
for big animals, computer techniques and skilled personel to handle animals and techniques. All these facilities are rarely present at one location which may be the reason for the scarce number of such investigations. Other reasons may be the high costs, the intensity of studies during a relatively short lactation period, and the time which is often limited to two-four years for Ph.D. or post doc studies. The advantages by the present methods are that they are non-invasive or require a minimum of incisions, blood sampling and handling of the animals, whereby stress is limited, and repeated measurements can be carried out. The present methods keep the animals under confined space with limited opportunities for physical activity (standing and lying). The use of heart rate as an indicator of heat production or even physical activity may be one method which could be developed into wireless transmitters and thereby be used for freely moving animals as has been described for measurements on free living deer (Theil et al., 2004a). The DLW method is being used in humans to study energy metabolism in health and disease while they are living under normal conditions (e.g., Westerterp et al., 1991; Wierik et al., 1995). However, the costs of ${ }^{18} \mathrm{O}$ are very high. The approximate costs were 200 US \$ for enriching one piglet once. Due to the relative limited moving conditions of the sow, which as a matter of fact correspond to the present situation on the farms, it is necessary to select sows with strong legs. Leg weakness and mastitis are complications in such intensive studies. Prophylactic treatment against mastitis before farrowing is advisable. Furthermore, the sows should be adapted to stand in the metabolism cage before farrowing.

Protein (nitrogen) metabolism was obtained by the balance technique described in equation 2 and results are shown in Table 2. These measurements do not require respiration chambers, but collection of faeces and urine must be carried of without evaporative loss of ammonia. This may be obtained by acidifying the urine to a $\mathrm{pH}$ below 4 and by using catheters inserted in the urinary bladder to allow the urine to run directly into the beakers with acid (Fernandez et al., 1986). In the present studies we did not use urinary catheters to avoid the risk of infection and the risk that they would be damaged by the piglets. Therefore, some loss of nitrogen may have occurred which will result in an overestimation of the nitrogen retention. The $\mathrm{RN}$ was positive throughout lactation but decreased from $15 \mathrm{~g} \mathrm{RN} \mathrm{d}^{-1}$ in week 2 to 3-4 $\mathrm{g} \mathrm{RN} \mathrm{d}^{-1}$ in week 4, coinciding with a significantly higher milk production and probably a decreased allocation of energy and protein to mammary gland growth (Kim et al., 1999). Consequently, the utilization of $\mathrm{N}$ for milk production increased with progress of lactation. In total, $49 \%$ of the $\mathrm{N}$ intake was excreted in the milk, which was identical to the results of Noblet and Etienne (1987a) at a similar feeding level. We consider in future studies to measure the urine production quantitatively by means of osmotic pumps either with ${ }^{3} \mathrm{H}$-labelled para-aminohippuric acid (PAH) or ${ }^{14} \mathrm{C}$-inulin by Wamberg et al. (1996). 
Fat metabolism was deduced from equation (6). As seen in Table 4 the sows mobilized fat during the whole lactation period. Apparently, the intake of energy was not sufficient to cover the energy requirement for milk production which is a problem in modern production as pointed out by Neil et al. (1996) and Cole (1990). The present studies suggest that the energy supply rather than the protein supply is the limiting factor for milk production.

The milk production was estimated by the $\mathrm{D}_{2} \mathrm{O}$ dilution technique. Three reasons caused selection of this method in favour of the weigh - suckle - weigh (WSW) method. The WSW method may underestimate the milk production owing to 1 . urination, defaecation, loss of saliva and metabolic water between the two weighings, 2 . WSW may depress the milk production due to interruption of the interrelationship between the lactating sow and the suckling piglets (Klaver et al., 1981; Pettigrew et al., 1985) and 3. as HE of piglets was measured by the DLW method, the milk intake could be determined without extra labour. A previous study (Theil et al., 2002b) showed that repeated determination of milk intake in three median piglets per litter was sufficient to predict the milk produced by the sow accurately $\left(\mathrm{R}^{2}=0.99\right)$. Using, the $\mathrm{D}_{2} \mathrm{O}$ method on all piglets in the litter gave a milk production of the sow of $9.91 \pm 0.69 \mathrm{~kg} \mathrm{~d}^{-1}$, and on three median piglets a similar production of $9.87 \pm 0.74 \mathrm{~kg} \mathrm{~d}^{-1}(\mathrm{P}>0.05)$, whereas the WSW method without corrections for loss of urine, faeces and saliva gave a significantly $(\mathrm{P}<0.05)$ lower milk production of $8.65 \pm 0.81 \mathrm{~kg} \mathrm{~d}^{-1}$ (Theil et al., 2002b). The approach where three median piglets were enriched in order to predict the whole litter performance was developed in order to reduce the costs when piglets were enriched with doubly labelled water. The use of $\mathrm{D}_{2} \mathrm{O}$ assumes that the piglets do only receive sow milk. Therefore, the piglets must be kept away from the sow's trough and urine. Recycling of isotopes due to e.g., licking has not been a problem in our studies, which was checked by having a non-enriched piglet as a control in each litter.

For ethical reasons, the comparative slaughter technique is not frequently used when studying energy metabolism in lactating animals. When using indirect calorimetry either the RQ- or the CN-method respiration chambers must be available. In order to sustain milk production the piglets must join the sow, whereby they contribute to the gas exchange measurements. We have used different approaches to separate HE of sow and piglets as shown in Table 3.

The total HE of sow + litter increased considerably from week to week, but the sow HE remained rather constant irrespectively of the five methods (Heart rate, DLW, RQ, CN and FA pig), which yielded similar results. In contrast, HE estimated factorially for the sow increased with progress of lactation. The simplest and cheapest way to estimate the contribution of the sow and the piglets is to divide the gas exchange according to metabolic LW (RQ-method). The HRmethod, DLW and FA pig agreed well with the RQ-method. In contrast, the CN- 
method estimated sow HE 7.6\% lower than the RQ-method, probably because the N-balance was overestimated. Differences between the RQ- and CN-methods are normally small, but may be influenced by fat metabolism and other factors as found in growing pigs (Christensen et al., 1988), while no studies comparing the two methods in lactating sows seem to have been performed. Conversely, the sow factorial method overestimated the sow HE, especially in late lactation. FA sow underestimated HE of litter by $15 \%$. Measurements of piglet HE by the DLW method and sow HE by using HR were independent, and ideally the sum of these components should amount to total HE of sow + litter measured by indirect calorimetry.

The present studies indicate that the DLW and the HR methods were reliable as the sum of sow HE found by HR and litter HE found by DLW on average yielded $99.3 \%$ of total HE measured according to the RQ-method. In conclusion the DLW-method gave reliable results both concerning estimation of litter HE and sow milk yield. The HR-method gave similar results of HE, which is promising as to measurements of sow HE under loose- housed or free-ranging conditions, but also the simplest method, separation of gas exchange according to $\mathrm{kg}^{0.75}$ gave reasonable data.

In the lactation period $57 \%$ of ME was excreted in milk and $50 \%$ of ME was lost as heat (Table 4), yielding a slightly negative energy balance of $6.4 \%$ of ME. The standing activity only amounted $3.9 \%$ of ME and $8 \%$ of HE, and was rather constant during the lactation period. Physical activity is part of HE. In growing pigs kept in metabolic cages with reduced possibility for physical activity, standing is the main activity and accounted for $8 \%$ of maintenance requirement at high feeding level (Susenbeth and Menke, 1991). The present standing activity of $54 \mathrm{~kJ} \mathrm{~kg}^{-0,75} \mathrm{~d}^{-1}$ would account for $11.2 \%$ of $\mathrm{ME}_{\mathrm{m}}$. The higher level in the sow may be due to the bigger mass to be moved. Heat production and quantitative oxidation of nutrients by physical activity in pigs has been discussed by Jakobsen et al. (1994). The constant HE with increasing progress of lactation appeared striking, as the feed intake and the milk production concomitantly increased, and changes of physical activity or heat production per $\mathrm{kg}$ DM of feed could not account for this. The discrepancy could then be due to a lower ME for maintenance $\left(\mathrm{ME}_{\mathrm{m}}\right)$, or to a higher efficiency of ME for milk production $\left(\mathrm{k}_{\mathrm{l}}\right)$. As the mammary glands grow throughout lactation (Kim et al., 1999), a declining $\mathrm{ME}_{\mathrm{m}}$ is contradictory. By assuming a constant $\mathrm{ME}_{\mathrm{m}}$ (estimated as $482 \mathrm{~kJ} \mathrm{LW}, \mathrm{kg}^{-0.75} \mathrm{~d}^{-1}$ ) $\mathrm{k}_{1}$ was found to be $0.77 \pm 0.01,0.78 \pm 0.01$ and $0.81 \pm 0.01$ for weeks 2,3 and 4 , respectively of the lactation period. Consequently, a decreased RE in the udder may have elevated $\mathrm{k}_{1}$ whereby HE was kept constant. The decreased $\mathrm{RN}$ with progress of lactation support this hypothesis.

The present studies also allow an explanation of the substrates oxidized to yield total HE. The main contribution was from carbohydrates $(82 \%), 13 \%$ from 
protein and about $5 \%$ from fat. The overall pattern of substrate oxidation was similar to that of growing pigs (Chwalibog et al., 1992).

For future studies it may be advantageous to use the bicarbonate method to measure the $\mathrm{CO}_{2}$ production of the piglets to estimate their heat production. Bicarbonate $\left(\mathrm{HCO}_{3}^{-}\right)$is enriched with ${ }^{13} \mathrm{C}$ and injected (or ingested), and ${ }^{13} \mathrm{C}$ is analysed in $\mathrm{CO}_{2}$ of expired air (Elia, 1991). The bicarbonate method is much cheaper than the DLW method, which allows a high excess enrichment.

\section{CONCLUSIONS AND PERSPECTIVES}

Studies on lactating sows are difficult because the piglets must stay with the sow to sustain milk production. An insight in metabolism of nutrients and energy in the lactating sow and her piglets can be obtained by combining indirect calorimetry, balance experiments, stable isotope techniques and telemetry. By using indirect calorimetry in respiration chambers combined with $\mathrm{N}$ - and C-balances, a balance of input and output of protein, carbohydrates, fat and energy may be established. Milk production measured by deuterated water turnover of three median piglets gives a better estimate than the weigh-suckle-weigh method and may be combined with ${ }^{18} \mathrm{O}$ in the DLW-method or ${ }^{13} \mathrm{C}$ in the bicarbonate method, whereby the $\mathrm{CO}_{2}$ production from the piglets and hence the litter can be measured and $\mathrm{HE}$ derived. Measuring heart rate of the sow by telemetry is another promising approach which may in future be adapted for measurements on free-ranging sows kept indoor or outdoor. The developing -omics techniques (proteomics, metabonomics, nutrigenomics) may provide us with greater insight in metabolic pathways and their regulations, but quantitative studies have to be strengthened in order to fully understand metabolic disorders and how to prevent them. A combination of the methods might be a strong tool to obtain this objective.

\section{REFERENCES}

Brouwer E., 1965. Report og sub-committee on constants and factors. 3. Symposium on Energy Metabolism, Troon 1964. EAAP Publication No. 11, pp. 441-443

Christensen K., Chwalibog A., Henckel S., Thorbek G., 1988. Heat production in growing pigs calculated according to the RQ and CN methods. Comp. Biochem. Physiol. Pt. A 91, 463-468

Chwalibog A., Jakobsen K., Henckel S., Thorbek G., 1992. Estimation of quantitative oxidation and fat retention from carbohydrate, protein and fat in growing pigs. J. Anim. Physiol. Anim. Nutr. $68,123-135$

Cole D.J.A., 1990. Nutritional strategies to optimise reproduction in pigs. J. Reprod. Fertil., Suppl. 40, 67-82

Elia M., 1991. Estimation of short-term energy expenditure by the labelled bicarbonate method. In: R.G. Whitehead, A. Prentice (Editors). New Techniques in Nutritional Research. Academic Press, New York, NY, pp. 207-227 
Fernandez J.A., Jørgensen H., Just A., 1986. Comparative digestibility experiments with growing pigs and adult sows. Anim. Prod. 43, 127-132

Fink R., Tauson A.-H., Chwalibog A., Hansen N.E., Kristensen N.B., Wamberg S., 2004. Effects of substitution of dietary protein with carbohydrate on lactation performance in the mink (Mustela vison). J. Anim. Feed. Sci. 13, 647-664

Jakobsen K., Chwalibog A., Henckel S., Thorbek G., 1994. Heat production and quantitative oxidation of nutrients by physical activity in pigs. Ann. Nutr. Metab. 38, 1-7

Jørgensen H., Zhao X.-Q., Eggum B.O., 1996. The influence of dietary fibre and environmental temperature on the development of the gastrointestinal tract, digestibility, degree of fermentation in the hind-gut and energy metabolism in pigs. Brit. J. Nutr. 75, 365-378

Kim S.W., Hurley N.L., Han I.K., Easter R.A., 1999. Changes in tissue composition associated with mammary gland growth during lactation in sows. J. Anim. Sci. 77, 2510-2516

King R.H., Williams I.H., Barker I., 1984. The effect of diet during lactation on the reproductive performance of first-litter sows. Proc. Aust. Soc. Anim. Prod. 15, 412-415

Klaver J., van Kempen G.J.M., de Lange P.G.B., Verstegen M.W.A., Boer H., 1981. Milk composition and daily yield of different milk components as affected by sow condition and lactation/feeding regimen. J. Anim. Sci. 52, 1091-1097

Lifson N., McClintock R., 1966. Theory of use of the turnover rates of body water for measuring energy and material balance. J. Theor. Biol. 12, 46-74

Littell R.C., Milliken G.A., Stroup W.W., Wolfinger R.D., 1996. SAS® System for Mixed Models. Cary, NC, SAS Institute Inc.

Moustsen V.A.A., Poulsen H.L., Nielsen M.B.F., 2004. Dimensions of cross-bred sows. In: National Committee for Pig Breeding, Health and Production, Axelborg, Copenhagen. Meddelelse No. 649, pp. 10

Neil M., Ogle B., Anner K., 1996. A two-diet system and ad libitum lactation feeding of the sow: 1. Sow performance. Anim. Sci. 62, 337-347

Noblet J., Etienne M., 1987a. Metabolic utilization of energy and maintenance requirements in lactating sows. J. Anim. Sci. 64, 774-781

Noblet J., Etienne M., 1987b. Body composition, metabolic rate and utilization of milk nutrients in suckling piglets. Reprod. Nutr. Develop. 27, 829-839

Noblet J., Shi X.S., Dubois S., 1993. Energy cost of standing activity in sows. Livest. Prod. Sci. 34, $127-136$

Pettigrew J.E., Sower A.F., Cornelius S.G., Moser R.L., 1985. A comparison of isotope dilution and weigh - suckle - weigh methods for estimating milk intake by pigs. Can. J. Anim. Sci. 65, 989-992

Susenbeth A., Menke K.H., 1991. Energy requirement for physical activity in pigs. Proceedings of $12^{\text {th }}$ Symposium on Energy Metabolism. EAAP Publication No. 58, pp. 416-419

Theil P.K., Coutant A.E., Olesen C.R., 2004a. Seasonal changes and activity - dependent variation in heart rate of roe deer. J. Mammal. 85, 245-253.

Theil P.K., Jørgensen H., 2002. Estimation of heat production in lactating sows by means of heart rate. Nordic Telemetry User Group Meeting: "The Use of Telemetry in Experimental Pharmacology and Drug Development”. H. Lundbeck, Copenhagen, Abstr. pp. 5-6

Theil P.K., Jørgensen H., Jakobsen K., 2002a. Energy and protein metabolism in pregnant sows fed two levels of dietary protein. J. Anim. Physiol. Anim. Nutr. 86, 399-413

Theil P.K., Jørgensen H., Jakobsen K., 2004b. Energy and protein metabolism in lactating sows fed two levels of dietary fat. Livest. Prod. Sci. 89, 265-276

Theil P.K., Jørgensen H., Jakobsen K., Kristensen N.B., 2003. Validation of measuring $\mathrm{CO}_{2}$ production and milk intake by doubly labelled water in piglets. In: W.B. Souffrant, C.C. Metges 
(Editors). Proceedings of $16^{\text {th }}$ Energy Symposium, Rostock (Germany). EAAP Publication No. 109, pp. 561-564

Theil P.K., Nielsen T.T., Kristensen N.B., Labouriau R., Danielsen V., Lauridsen C., Jakobsen K., 2002b. Estimation of milk production in lactating sows by determination of deuterated water turnover in three piglets per litter. Acta Agr. Scand., Sect. A, Anim. Sci. 52, 221-232

Verstegen M.W.A., Mesu J., Kempen G. van, Geerse C., 1985. Energy balances of lactating sows in relation to feeding level and stage of lactation. J. Anim. Sci. 60, 731-740

Wamberg S., Elnif I., Tauson A.H., 1996. Assesment of the accuracy of quantitative urine collection in mink (Mustela vision) using osmotic pumps for continuous release of $\mathrm{p}$. amino-hippuric acid and inulin. Lab. Anim. 30, 267-275

Westerterp K.R., Saris W.H.M., Soeters P.B., ten Hoor F., 1991. Determinants of weight loss after vertical banded gastroplasty. Int. J. Obesity 15, 529-534

Wierik Velthuis-te E.J.M., Westerterp K.R., van den Berg H., 1995. Impact of a moderately energy - restricted diet on energy metabolism and body composition in non-obese men. Int. J. Obesity $19,318-324$

\section{STRESZCZENIE}

\section{Pomiary metabolizmu składników odżywczych i energii u karmiących loch - rozważania metodologiczne}

Opisano badania nad przemianą białka, tłuszczu, węglowodanów i energii u 8 karmiących loch i prosiąt. Pobranie składników odżywczych i energii, związków azotu (N) i węgla (C) oraz ich wydalanie w kale, moczu, mleku i gazach mierzono w komorach respiracyjnych, podczas gdy do obliczenia produkcji ciepła (HE) i metanu $\left(\mathrm{CH}_{4}\right)$ zastosowano metody kalorymetrii pośredniej. Mierzono całkowitą produkcję HE (locha + prosięta), ponieważ prosięta musiały być przy lochach w trakcie pomiarów. Udział całkowitej energii (HE) przypadającej na lochę lub prosięta określano różnymi metodami. Produkcja mleka u loch była mierzona przy pomocy wskaźnika rozcieńczenia ciężkiej wody $\left(\mathrm{D}_{2} \mathrm{O}\right)$. Przez użycie podwójnie znakowanej wody $\left(\mathrm{D}_{2}{ }^{18} \mathrm{O}\right) \mathrm{u}$ trzech prosiąt $\mathrm{z}$ miotu mierzono $\mathrm{z}$ dużą dokładnością produkcję $\mathrm{CO}_{2}$ równocześnie z produkcją mleka. Produkcję $\mathrm{HE}$ u loch, po implantacji przekaźnika telemetrycznego, mierzono na podstawie rejestracji liczby uderzeń serca. Dodatkowo udział całkowitej HE mógł być określony dla HE loch i HE prosiąt z wyników wymiany gazowej na podstawie metabolicznej masy ciała ( $\mathrm{LW}, \mathrm{kg}^{0,75}$ ) loch i prosiąt oraz przy zastosowaniu metod czynnikowych. Aktywność fizyczną loch rejestrowano przy użyciu fotokomórki. W pracy przedyskutowano zalety i wady stosowanych metod. 